\title{
THE ADJACENCY PAIRS IN "TALK ASIA" INTERVIEW BETWEEN INDONESIA PRESIDENT SUSILO BAMBANG YUDHOYONO WITH STEVENS FROM CNN
}

\author{
Ai Siti Nurhasanah ${ }^{1}$, Ajeng Febrina Yolanda ${ }^{2}$, Trisnendri Syahrizal ${ }^{3}$ \\ ${ }^{1}$ IKIP Siliwangi \\ ${ }^{2}$ IKIP Siliwangi \\ ${ }^{3}$ IKIP Siliwangi \\ ${ }^{1}$ Asnurhasanah97@gmail.com, ${ }^{2}$ febrinaajeng25@gmail.com, ${ }^{3}$ trisnendri@ikipsilwangi.ac.id
}

\begin{abstract}
This research focus on adjacency pairs in "Talk Asia" Interview between President SBY with Stevens from CNN. This research had aimed to find out what types of AP and preference structure used in"Talk Asia” Interview between Indonesian President SBY with Stevens from CNN. Qualitative method was used to analyze this research. The researchers take the interview from CNN between Indonesia president SBY with Stevens as the instrument for research. The result found that was four question-answer, two assessment-agreement/disagreement, one request-acceptance/refusal, one farewell-farewell, it means that the dominant type of AP in "Talk Asia" Interview between Indonesia President SBY with Stevens from $\mathrm{CNN}$ is question-answer. For preference structure there are two preferred and one dispreferred.
\end{abstract}

Keywords: Adjacency Pairs, Preference Structure

\section{INTRODUCTION}

Speaking most commonly do by people everyday. By speaking people can express their feeling, opinion spontaneously. Also, speaking is an activity used by people to communicate. It takes place everywhere and commonly used in our daily activities. When people speak, they interact and use the language to express their ideas, feeling and thought. They also share information to other through communication (Ningtyas, 2014:1) in (Argawati, N. O., \& Syahrizal, 2016). In addition (Brown, 1994; Burns and Joyce, 1997) cited in (Florez, 1999) state that speaking is an interactive process of constructing meaning that involves producing and receiving and processing information. It is often spontaneous, open-ended, and evolving. Spoken language is a wide subjet and little is known in hard applied mathematics terms of the distribution of various types of speech in people's everyday life. If we list at random a number of different types of spoken language and consider how much of each day or week we spend engaged in each one, we can only roughly guess at some sort of frequency ranking, other than to say that casual conversation is almost certainly the most frequent for most people (McCarthy, 1991). Some different types of speech might be classroom (classes, seminars, lectures, tutorials), language in action (Talk accompanying doing: fixing, cooking, assembling, demonstrating, etc.), interviews (jobs, journalistic, in official setting).

The researcher takes an interview between Indonesia President SBY with Stevens from CNN as the instrument for research. According to Kvale (1996: 174) in (Alshenqeeti, 2014) an interview is "a conversation, whose purpose is to gather descriptions of the [life-world] of the interviewee" with respect to interpretation of the meanings of the 'described phenomena.'In a similar statement of Schostak (2006: 54) cited in (Alshenqeeti, 2014) adds that an interview is an extendable conversation between partners that aims at having an 'in-depth information' 
about a certain topic or subject, and through which a phenomenon could be interpreted in terms of the meanings interviewees bring to it. It can be conclude that interview is a conversation that aim at gathering information. The world of conversation has an automatic pattern in the structure of the conversation called adjacency pair. Adjacency pairs is pairs of utterances in talk are often mutually dependent (McCarthy, 1991) a most obvious example is that question predicts an answer, and that an answer presupposes a question predicts an answer, and that and answer presupposes a question. According to (Schegloff \& Sacks, n.d.), the AP are composed a two turn by different speakers with each turn being adjacently placed one after the other. (Schegloff \& Sacks, n.d.) divide the AP into nine parts, such as greeting-greeting, questionanswer, request-refusal, command compliance/incompliance, blame/accusation admission/denial, offer-acceptance or refusal, assertion-agreement, disagreement, summonsanswer, and farewell-farewell. It is possible to state the requirements, in a normal conversational sequence, for many types of utterances, in term of what is expected as a response and what certain responses presuppose (McCarthy, 1991). According to Levinson (1983:303) in (Bintana, Rukmini, Sofwan, \& Semarang, 2018) adjacency pairs are inter-related with the turn-taking system as techniques for selecting a next speaker (especially where an address term is included or the content of the first utterance of the pair clearly isolates a relevant next speaker). Statement from (Yule, 1996) states that the two turns making up the adjacency pairs are relatively ordered distinguish by a first pair part (FPP) and second pair part (SPP). First part that contains a requestion invitation call for participation|asking|letter of invitation|missive of invitation or a suggestion is typically made within the expectation that the next part will be an acceptance. An acceptance is structurally being called preference. This research had aimed to find out what types of adjacency pairs and preference structure used in"Talk Asia" Interview between Indonesian President SBYwith Stevans from CNN.

\section{METHOD}

This research used qualitative method. In preparing the data the researchers did not only collect tha data but also selected and classified tha data according to particular clssifications that had been prepared. In collecting the data from written sources, the researchers applied read and write technique. The data analysis in this study was done by analyzing the data obtained and then classifying them into two clasifications : the type and preference structure of the adjacency pairs. The data then clasified into the type of AP namely: question-answer, assessmentagreement/disagreement, request-acceptance/refusal, farewell-farewell. Preference structure : preferred and dispreferred.

\section{RESULTS AND DISCUSSION}

\section{Results}

In this part the researchers discuss about types of AP and preference structure in "Talk Asia" Interiew between Indonesian President SBY with Stevens from CNN. The researchers found four types of AP. There are four data of questions-answers, two data of assessmentagreement/disagreement, one data of request-acceptence/refusal, one data of farewel-farewel. Furthermore in the preference structure there are two data that are one data of preferred and one data of dispreferred.

\section{Discussion}

1. Types of AP in "Talk Asia" Interview between Indonesian President SBYwith Stevans from $\mathrm{CNN}$ : 


\section{a. Question-Answer}

\section{Data I}

Stevens: Foreign investment is pouring in, now. If you look at the investment grade, it's about to get investment grade rating probably within 12 months or so. A growth rate of 6 1/2 percent, perhaps stronger to come. Is this growth at this level now sustainable?

SBY: Yes, this is a great challenge for Indonesia. To maintain sustainability of our economic growth.

The utterances above are one of types of AP that is question-answer because the first part is asking a question and the second part is answering a question. They talk about economy, stevens wants to know whether the growth of foreign investment in Indonesia sustainable and SBY answers "Yes". He states to maintain sustainability of Indonesian economic growth.

\section{Data II}

Stevens: I've been talking to business people inside and outside of Indonesia. And the one thing they virtually all tell me is that a lack of modern infrastructure is holding back growth in Indonesia. What is your government doing about that?

SBY: In the next five to 10 years, we have plans to prioritize infrastructure development. Be it ports, airports, transport, power plants, and other infrastructure that is needed.

\section{Data III}

Stevens: The U.S. President, Barak Obama, will again visit Indonesia this year. How are relations between the U.S. and Indonesia?

SBY: Bilateral relations between the U.S. and Indonesia are in good condition. We have a comprehensive partnership, which was signed during President Barak Obama's visit here last year. This process was initiated in 2008. Overall, our relationship is moving on well and there's plenty of opportunities to strengthen our cooperation.

The utterances are question-answer adjacency pairs because the first part steven asks how the relations between US and Indonesia then SBY answers that Bilateral relations between the US and Indonesia are in good condition. 


\section{Data IV}

Stevents: In your opinion, Mr. President, how big is the radical movement?

SBY: I have to say that there are still a few cells within our society. Radicalism or extremism has existed for many years in Indonesia. Amid international developments, there have been influences from the Middle East in Indonesia or from other places. Radicalism is rising, but I can't say how big they are in terms of percentage.

Stevents asks SBY's opinion about how big the radical movement is, and SBY answers radicalism or extremism has existed for many years in Indonesia. But he can't say how big they are in terms of percentage. These utterances are queastion-answer adjacency pairs.

\section{b. Assessment-Agreement/Disagreement}

\section{Data I}

Stevens: The corruption watchdog, Transparency International, still rates Indonesia quite poorly on their corruption index.

SBY: Corruption is, indeed, our biggest challenge. My biggest challenge. I have to be frank on that. In fact, since I assumed office in 2004, Indonesia has launched the most aggressive anti-corruption campaign in our history. And the results speak for themselves. About 150 senior officials have faced the law and some of them have been convicted and sent to jail. And there is now a big movement in our society against corruption.

The utterances above indicate that Stevens makes an assessment about Indonesia quite poorly on their corruption index, and SBY tells to Stevens that he agrees what steven says by saying Corruption is, indeed, our biggest challenge. My biggest challenge. I have to be frank on that. The utterances indicate that SBY agrees with Stevents' statement. 


\section{Data}

Stevens: You were reelected in 2009 in a landslide victory. Your popularity rating around the time was about 90 percent. But, there are those who will say you have not spent your political capital enough. That you have not been bold enough in reforms, in tackling extremism. What would you say to those people? How would you respond to that?

SBY: During the elections in both 2004 and 2009, I got 60 percent of the vote. But Indonesia is a multi-party democracy and my party, Party Democrat, won only 26 percent of the seats in parliament. It's not even 30 percent - far from half. In terms of the fight against terrorism and radicalism, I think I've been very clear about this. I was a target of three assassination attempts, including a bomb aimed to be exploded at my home. This proves that I've never doubted or feared in fighting terrorism and radicalism.

The first part Stevents makes assessments that SBY got 90 percent of the vote and he has not spent his political enough. That he has not been bold enough in reforms, in tackling extremism. SBY responds stevents' assessment by saying he got 60 percent of the vote, In terms of the fight against terrorism and radicalism, he thinks he has been very clear about this. He was a target of three assassination attempts, including a bomb aimed to be exploded at my home. He says that he has never doubted or feared in fighting terrorism and radicalism. The SBY's response indicate that he does not agree or accept with Stevents' assessments.

\section{c. Request-Acceptance/Refusal}

\section{Data I}

Stevens : Can I just ask you one more question, just about your music - your love of music? Do you mind?

SBY: Go ahead.

The utterances above are request-acceptance adjacency pairs because stevents asks for asking one more question about music and SBY answers go ahead. SBY's response indicate that he does not mind or accept Stevents' request. 


\section{d. Farewell-Farewell}

\section{Data I}

Stevents : Mr. President, thank you so much for your time.

SBY : You're welcome.

Stevents : It's been a great honor. Thank you.

SBY : Thank you, thank you.

The conversation above is adjacency pairs in the form of farewell-farewell. The conversation happens after a long diaolgue, stevents says farewell to SBY and SBY says farewell to Stevents too.

\section{The Preference Structure in "Talk Asia" Interview between Indonesian President SBY with Stevens from CNN}

\section{a. Preferred}

\section{Data I}

Stevens: The corruption watchdog, Transparency International, still rates

Indonesia quite poorly on their corruption index.

SBY : Corruption is, indeed, our biggest.

The conversation above contains preferred structure because the first part make assessment about rates Indonesia quite poorly on their corruption index and the second part respond to the assessment, it means that second part contains preferred structure by saying corruption is, indeed, our biggest challenge. My biggest challenge. I have to be frank on that.

\section{Data II}

Stevens : Can I just ask you one more question, just about your music - your love of music? Do you mind?

SBY: Go ahead.

The first part make a request by saying can I just ask you one more question and second part responds it. The conversation contains preferred structure because the next part responds to the request by saying go ahead. 


\section{b. Dispreferred}

Stevents: There are those who will say you have not spent your political capital enough. That you have not been bold enough in reforms, in tackling extremism.

SBY: In terms of the fight against terrorism and radicalism, I think I've been very clear about this. I was a target of three assassination attempts, including a bomb aimed to be exploded at my home. This proves that I've never doubted or feared in fighting terrorism and radicalism.

The conversation above contains dispreferred structure because the second part express disagreement toward Stevents' utterances by saying he never doubted or feared in fighthing terrorism and radicalism.

\section{CONCLUSION}

After analyzing the data the researcher conclude that there are some types of adjacency pairs happen in "Talk Asia" Interview between Indonesia President SBY with Stevans from CNN that are four question-answer, two assessment-agreement/disagreement, one requestacceptance/refusal, one farewell-farewell, it means that the dominant type of adjacency pairs in "Talk Asia" Interview between Indonesia President SBY with Stevens from CNN is questionanswer. For preference structure there are two preferred and one dispreferred.

\section{ACKNOWLEDGMENTS}

Alhamdulillahi rabbil'alamin all gratitude to Allah S.W.T who gave His blessing, health, opportunity to researchers, so researchers can finish this article with good health condition. Researcher would like to say thank you to a lot of people have provided motivation, advice, and support for the researcher when conducting this article. Also, researchers would like to say thank you to lecture of Discourse Analysis Mrs.Ida Lisdawati, M.Hum and to our supervisor Mr. Trisnendry Syahrizal, M.Hum which gave us opportunity to conduct this article.

\section{REFERENCES}

Alshenqeeti, H. (2014). Interviewing as a Data Collection Method: A Critical Review. English Linguistics Research, 3(1), 39-45. https://doi.org/10.5430/elr.v3n1p39

Argawati, N. O., \& Syahrizal, T. (2016). The Use Of Task-Based Instruction To Improve Speaking Skill To The Second Semester Students Of Stkip Siliwangi Bandung On The Academic Year Of 2014-2015. Jurnal Ilmiah UPT P2M STKIP Siliwangi, Vol.3(1), 1-8.

Bintana, K., Rukmini, D., Sofwan, A., \& Semarang, U. N. (2018). The Adjacency Pairs Patterns of Trumps 'Victory Interview in ' 60 Minutes .' 8(1), 18-26.

Florez, M. A. C. (1999). Improving Adult English Language Learners' Speaking Skills. Burns, (June), 1-4.

McCarthy, M. (1991). discourse analysis for language teachers. cambridge, united kingdom: cambridge university press.

Schegloff, E. A., \& Sacks, H. (n.d.). Opening up Closings *. 49(638).

Yule, G. (1996). pragmatic. united kingdom: oxford university press. 
